\title{
THE INFLUENCE OF CELEBRITY ENDORSER, PRODUCT QUALITY AND PRICE ON PURCHASE DECISIONS AND CUSTOMER SATISFACTION ON VIVO BRAND SMARTPHONES IN SURABAYA
}

\author{
Andi Muh Kumar Lkํㅗ I Gede Arimbawa ${ }^{2}$, Elok Damayanti ${ }^{3}$

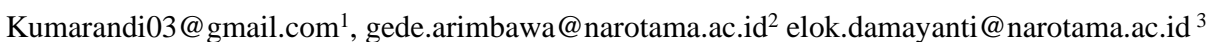 \\ Departement of Management, Faculty of Economic and Business \\ Narotama University, Surabaya, Indonesia
}

\begin{abstract}
Smartphone is a virtual communication tool in two directions that makes easy for individuals to interact through short message, telephone and an internet network. The purpose of this study was to analyze the influence of celebrity endorser, product quality and price on purchasing decisions and customer satisfaction. This research used quantitative methode with population 100 respondents who use Vivo brand smartphones in Surabaya. The analysis used partial least square, data obtained from questionnaires and tested with the SmartPLS 3.0. The results showed that the variable celebrity endorser, product quality and price had a significant effect on purchasing decisions, and purchasing decisions have a significant effect on customer satisfaction. Conclusion showed that sponsor more look for customers who using Vivo smartphones, which have affordable or discounted prices so customers make reapeat purchase and satisfied.
\end{abstract}

Keywords: : Celebrity Endoser, Product Quality, Price, Purchase Decision, Customer Satisfaction.

\section{INTORDUCTION}

Smartphone is a virtual communication tool in two directions that makes it easy for each individual to interact with other individuals only through short message assistance, telephone, and the most rapid development at this time is using the internet network, smartphone is just a telephone that presents advanced features such as email (electronic mail), internet and the ability to read electronic books (e-books) and others.

Users in Indonesia smartphones have experienced increases, based on the comScore MMX Multi-Platform site, May 2018, saying that $82 \%$ of netizens in Indonesia access mobile web are more, while $9 \%$ access on mobile web and via desktop. The composition of smartphone users, more than $70 \%$ of netizens only use smartphones to access information. This percentage is higher than other countries such as Mexico, Spain, China and US events.

Smartphone vendors from China, Vivo, Oppo and Xioami continue to push the Indonesian market in the third quarter of 2018. IDC Indonesia research firm noted that the three vendors have captured 56 percent of the market share in Indonesia. Meanwhile, vendors from South Korea, Samsung, still dominate the Indonesian market with a percentage of 28 percent. Samsung's portion is 4 percent adrift of Xiaomi, which ranks second, shifting Oppo in the same period last year. Oppo itself dropped to third place with a market share of 19 percent, compared to the third quarter of 2017 which won 25.5 percent. Advan's local cellphone brand was crushed by Chinese vendors. Last year, Advan was still able to become the top three smartphone brands in Indonesia. But now he crashed into fifth place with a percentage of 5 percent, under Vivo in fourth place with a percentage of 11 percent.

\section{CONSEPTUAL REVIEW \\ Celebrity Endorser}

Celebrity endorser is an artist, entertainer, athlete, and public figure that many people know for the success of a supported product (A, Shimp, 2003). Celebrity endorser is defined as a figure who is well known by the public and exhibits as a consumer in advertising (Belch, Michael A, George E, 2004). These celebrity groups include television stars and movie stars, sports stars, politicians, businessmen, artists, and certain people from the military.

This study explores the influence of celebrity endorser variables on purchasing decisions and customer satisfaction, using the celebrity endorser indicator presented by (A, Shimp, 2003) that is :

1. Explicit, support the product

2. Implicit, using the product

3. Imperative, suggest using the product 
Hypothesis 1 : Celebrity endorsers have a significant effect on purchasing decisions.

Hypothesis 2 : Product quality has a significant effect on purchasing decisions.

\section{Product Quality}

(Kotler dan Armstrong, 2012) quality is a characteristic of a product in its ability to meet predetermined and definite needs. According to (Buchari Alma, 2007) quality is the advantage possessed by these products. Quality in the view of consumers is something that has its own scope that is different from the quality in the view of the producer when issuing a product that is commonly known as actual quality.

This research explores the effect of product quality variables on purchasing decisions and customer satisfaction, using product quality indicators proposed by (Tjiptono, 2008) that is : performance in a product, product durability, product features.

Hypothesis 3 : Price has a significant effect on purchasing decisions.

Hypothesis 4 : Supporters of celebrities have a significant influence on customer satisfaction.

\section{Price}

(Philip Kotler dan Gary Amstrong, 2008) in a narrow sense, price is a number of bills for a product or service. For the broad meaning, the price is the nominal amount that has been given by consumers in order to benefit from owning or using a product or service. This study uses the price indicator put forward by (Kotler dan Armstrong, 2012): affordability of prices, price compatibility with quality, price competitiveness, price compatibility with benefits.

Hypothesis 5 : Product quality has a significant effect on customer satisfaction.

Hypothesis 6 : Price has a significant effect on customer satisfaction.

\section{Purchasing Decision}

According to (Kotler, Philip., 2004) argues that: "purchasing decisions are the stage of the decision process where the consumer actually purchases the product". The purchasing decision making process consists of five stages: recognition of needs, information seeking, evaluating alternatives, purchasing decisions, and behavior after purchase. This study uses indicators of purchasing decisions according to (Philip, 2009) : needs and desires for a product, the desire to try, a decision to buy from who (supplier), a decision about the time to buy, a decision in the way of payment.

Hypotesis 7: Purchasing decisions significant effect on customer satisfaction.

\section{Customer Satisfaction}

(Tjiptono, 2008), the word customer satisfaction is a post-purchase evaluation where the chosen alternative will produce results (results) equal to or more than consumer expectations, while dissatisfaction will arise if the results obtained cannot meet customer expectations. This study uses indicators of customer satisfaction according to (Tjiptono, 2008): confirmation of hope, interest in repurchasing, no complaints about the product.

\section{Research Framework}

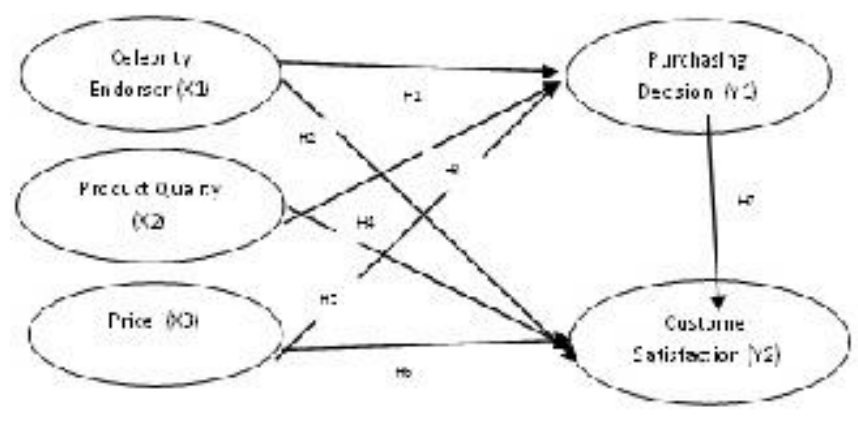

Figure 1 : Research framework

\section{METODOLOGY}

Research uses a quantitative approach is a method based on the philosophy of positivism, used to examine the population or a particular sample, data collection using research instruments, data analysis is quantitative / statistical, with the aim of testing what has been determined (Sugiyono, 2008). This research variable consists of independent variables, Celebrity endorser, Product quality and price. Intervening variables Purchasing decisions 
and variables are bound to customer satisfaction. The population in this study were consumers who use vivo cellphones in Surabaya, as many as 100 respondents. The data analysis technique uses Partial Least Square (PLS) with SmartPLS 3 software.

\section{RESULT AND DISCUSSION}

The R-Adjusted purchase purchase decision variable is 0.812 or $81.2 \%$. The results show that the independent variable celebrity endorser, product quality, and price contribute $81.2 \%$ to the purchasing decision and the remaining $18.8 \%$ is influenced by other factors, while the R-Adjusted customer satisfaction variable equal to 0.817 or $81.7 \%$, this result shows that the independent variable celebrity endoser, product quality and price contribute $81.7 \%$ and the remaining $18.3 \%$ is influenced by other factors.

In testing the hypothesis, a data must meet a criterion, and the hypothesis is said to be accepted if the tstatistic value is greater than t-table and if the p-value is less than 0.05 and vice versa.

The output of the SmartPLS is as follows:

Table 1 : Path Coefficient

\begin{tabular}{|l|c|c|}
\hline \multicolumn{1}{|c|}{ Path Coefficient } & t-statistic & p-value \\
\hline Celebrity Endorser $\rightarrow$ Purchase Decision & 6.829 & 0.000 \\
Celebrity Endorser $\rightarrow$ Customer Satisfaction & 2.999 & 0.001 \\
Product Quality $\rightarrow$ Purchase Decision & 3.372 & 0.000 \\
Product Quality $\rightarrow$ Customer Satisfaction & 2.392 & 0.009 \\
Price $\rightarrow$ Purchase Decision & 3.429 & 0.000 \\
Price $\rightarrow$ Customer Satisfaction & 2.041 & 0.021 \\
Purchase Decision $\rightarrow$ Customer Satisfaction & 2.551 & 0.005 \\
Celebrity Endorser $\rightarrow$ Purchase Decision $\rightarrow$ Customer Satisfaction & 2.426 & 0.008 \\
Product Quality $\rightarrow$ Purchase Decision $\rightarrow$ Customer Satisfaction & 2.274 & 0.012 \\
Price $\rightarrow$ Purchase Decision $\rightarrow$ Customer Satisfaction & 1.848 & 0.033 \\
\hline
\end{tabular}

Source, output SmartPLS 3.0, 2019

\section{Direct Influence}

Hypothesis 1 : Celebrity endorser on purchasing decisions

Based on the results of the analysis, it can be seen that the celebrity endorser is positive and significant towards the purchasing decision with the results of the p-value $0.000<0.050$ and the t-staistic value $>$ t-table which is $6.829>1.661$.

The results of this supported study by previous research conducted by (Suryani, 2016) entitled "The Influence of Celebrity Endorser, Brand Image, and Trust in the Purchase Decision of Male Biore Facial Cleansers" which states that Celebrity Endorsers partially have a positive and significant effect on the decision to purchase Biore Men products.

Hypothesis 2 : Celebrity endorser on customer satisfaction

Based on the results of the analysis, it can be seen that celebrity endorsers have a positive and significant effect on customer satisfaction with the results of p-value $0.001<0.050$ and t-staistik $>\mathrm{t}$-table, 2,999> 1,661.

The results of this study are supported by previous research conducted by (Pakpahan, 2017) entitled "The Influence of Celebrity Endorser Credibility on You-C 1000 Vitamin Purchasing Decisions and Customer Satisfaction in Pekanbaru City" which states that celebrity endorsers have a significant effect on the decision to purchase You-C 1000 Vitamins in Pekanbaru City.

Hypothesis 3 : Product quality on purchasing decisions

Berdasarkan hasil dari analisis dapat diketahui bahwa kualitas produk berpengaruh positif dan signifikan terhadap keputusan pembelian dengan hasil dari p-value $0.000<0.050$ dan nilai t-staistik $>\mathrm{t}$-table yaitu $3.372>$ 1.661.

The results of this study are supported by previous research conducted by (Sunarto, 2015) entitled "The Influence of Product Quality on Purchasing Decisions at the Kartika Magetan Leather Craft Shop" which states that there is a significant overall effect between product quality on purchasing decisions at the Kartika Magetan leather shop ". And research conducted by (Widayanti, 2016) entitled "The Influence of Product Quality and Prices on Decisions on the Purchase of Honda Motorcycles in Campus 1 Students of Krida Wacana Christian University" which states that product quality has a significant influence on purchasing decisions. 
Hypothesis 4 : Product quality on customer satisfaction

Based on the results of the analysis it can be seen that product quality has a positive and significant effect on customer satisfaction with the results of $\mathrm{p}$-value $0.009<0.050$ and $\mathrm{t}$-staistik $>\mathrm{t}$-table which is $2,392>1,661$.

The results of this study are supported by previous research conducted by (Putra, G. P., Arifin, Z., 2018) entitled "The Influence of Product Quality on Purchasing Decisions and Their Impacts on Consumer Satisfaction (Survey of Business Administration Students of the 2013 and 2014 Faculty of Administrative Sciences Universitas Brawijaya Purchasing Campus Data Packages)" which states that product quality has a significant effect on customer satisfaction. And research conducted by (Lenzun, 2014) entitled "The Effect of Product Quality, Prices and Promotions on Prepaid Telkomsel Card Customer Satisfaction" which states that product quality has a significant effect on Telkomsel prepaid card customer satisfaction.

Hipotesis 5 : Price on purchase decision

Based on the results of the analysis it can be seen that prices have a positive and significant effect on purchasing decisions with the results of p-value $0.000<0.050$ and t-staistik $>$ t-table which is 3.249>1.661.

The results of this study are supported by previous research conducted by (Widyawati, 2015) entitled "The Effect of Services and Prices on the Decision of Purchasing Samsung Brand Smartphones at UD. Surya Phone in Samarinda "which states that prices have a significant influence on Samsung's smartohone brand purchase decisions at UD. And the research conducted by (Widayanti, 2016) entitled "The Effect of Product Quality and Prices on Honda Motorcycle Purchase Decisions on Campus 1 Students of Krida Wacana Christian University" which states that prices have a significant influence on purchasing decisions.

Hipotesis 6 : Price on customer satisfaction

Based on the results of the analysis, it can be seen that prices have a positive and significant effect on customer satisfaction with the results of p-value $0.021<0.050$ and t-staistik $>$ t-table which is 2.041> 1.661 .

The results of this study are supported by previous research conducted by (Lenzun, 2014) entitled "The Effect of Product Quality, Prices and Promotions on Prepaid Telkomsel Card Customer Satisfaction" which states that prices have a significant effect on Telkomsel prepaid card customer satisfaction. This shows that the more affordable and according to price and the benefits offered to consumers, the more satisfied consumers feel after buying and using a Vivo brand Smartphone.

Hypothesis 7 : Purchase decision on customer satisfaction

Berdasarkan hasil analisis dapat diketahui bahwa keputusan pembelian berpengaruh positif dan signifikan terhadap kepuasan pelanggan dengan hasil p-value 0,005 <0,050 dan t-staistik $>$ t-table yaitu 2,551>1,661.

This shows that consumers who decide to purchase a Vivo brand smartphone, because consumers feel satisfied after buying and using a Vivo brand smartphone.

\section{Indirect Effects}

Celebrity Endorser for Customer Satisfaction through a Purchase Decision

The results of this study indicate that celebrity endorsers have a positive and significant indirect effect on customer satisfaction through purchasing decisions. This is because the p-value of $0.008<0.050$ and $\mathrm{t}$-statistics $>$ t-table 2.426>1,661.

This shows that with the celebrity endorser who is able to promote and convince Vivo products to customers by giving a positive image, the higher the feeling of satisfaction of consumers after buying and using a Vivo brand smartphone.

\section{Product Quality for Customer Satisfaction through Purchase Decisions}

The results of this study indicate that product quality has a positive and not significant effect on customer satisfaction through purchasing decisions. This is because p-value $0.012>0.050$ and t-statistic $<\mathrm{t}$-table 2,274 $<1,661$.

This shows that the better the quality of the product given to consumers in accordance with the needs and desires of consumers, the higher the level of satisfaction of customers after buying and using a Vivo brand smartphone.

\section{Price for Customer Satisfaction Through Purchasing Decisions}

The results of this study indicate that prices have a positive and significant effect indirectly through purchasing decisions. This is because the p-value of $0.033<0.050$ and t-statistics $>t$-table 1,848>1,661.

These results indicate that the more affordable and in accordance with the price.

\section{CONCLUSION}

From the results of processing the data above, it can be concluded that the variable celebrity endorser, product quality and price have a positive and significant influence on purchasing decisions and customer satisfaction. It showed that sponsor more look for customers who using Vivo smartphones, which have affordable or discounted prices so customers make reapeat purchase and satisfied. 


\section{LIMITATIONS}

The limitation of the results of this study is that this study has a limited location only around the city of Surabaya, therefore for further research it can be done by expanding the scope of research for example for all regions of Indonesia. In addition, further research can be developed through other independent variables.

\section{REFERENCES}

A, Shimp, T. (2003). Periklanan Promosi \& Apek Tambahan Komunikasi Pemasaran. (Edition 5). Jakarta: Erlangga.

Belch, Michael A, George E, B. (2004). Advertising and Promotion : An Integrated Marketing Communication Perspective (Six Editio). New York: McGrawhill.

Buchari Alma. (2007). Manajemen Pemasaran dan Pemasaran Jasa. Bandung: CV. Alfabeta.

Kotler, Philip., dan G. A. (2004). Dasar-Dasar Pemasaran (Ke Sembila). Jakarta: Indeks.

Kotler dan Armstrong. (2012). prinsip-prinsip pemasaran (13 jilid 1). Jakarta: Erlangga.

Lenzun, massie dan adare. (2014). Pengaruh kualitas produk, harga dan promosi terhadap kepuasan pelanggan kartu prabayar telkomsel. 1237-1245.

Pakpahan, E. S. B. (2017). PENGARUH KREDIBILITAS CELEBRITY ENDORSERTERHADAP KEPUTUSAN PEMBELIAN DAN KEPUASAN KONSUMEN YOU-C 1000 VITAMIN CDI KOTA PEKANBARU.

Philip, K. (2009). Manajemen Pemasaran (13th ed.). Jakarta: Erlangga.

Philip Kotler dan Gary Amstrong. (2008). Prinsip-prinsip Pemasaran (12 Jilid 1). Jakarta: Erlangga.

Putra, G. P., Arifin, Z., \& S. (2018). PENGARUH KUALITAS PRODUK TERHADAP KEPUTUSAN PEMBELIAN DAN DAMPAKNYA TERHADAP KEPUASAN KONSUMEN (Survei pada Mahasiswa Administrasi Bisnis Fakultas Ilmu Administrasi angkatan 2013 dan 2014 Universitas Brawijaya yang Melakukan Pembelian Paket Data Kampus). Clinical Genetics, 93(1), 78-83. Https://Doi.Org/10.1111/Cge.13031, 78-83.

Sugiyono. (2008). Metode Penelitian Kunatitatif Kualitatif dan $R \& D$. Bandung: Alfabeta.

Sunarto. (2015). PENGARUH KUALITAS PRODUK TERHADAPKEPUTUSAN EMBELIAN PADA TOKO KERAJINAN KULIT KARTIKA MAGETAN. EQUILIBRIUM.

Suryani, A. (2016). PENGARUH CELEBRITY ENDORSER , BRAND IMAGE DAN KEPERCAYAAN TERHADAP KEPUTUSAN PEMBELIAN PRODUK PEMBERSIH WAJAH MEN 'S BIORE Kadek Ayu Dwi Sudias Kumala Sukma 1 Fakultas Ekonomi dan Bisnis Universitas Udayana , Bali, Indonesia Kadek Ayu Dwi Sudias Kumala . 5(7), 4016-4043.

Tjiptono, F. (2008). service management. mewujudkan layanan prima (I). Yogyakarta: andi.

Widayanti, D. K. R. (2016). PENGARUH KUALITAS PRODUK DAN HARGA TERHADAP KEPUTUSAN PEMBELIAN SEPEDA MOTOR HONDA PADA MAHASISWA KAMPUS 1 UNIVERSITAS KRISTEN KRIDA WACANA Denny Kristian Rita Widayanti Fakultas Ekonomi Universitas Kristen Krida Wacana. Jurnal Ilmiah Manajemen Bisnis, 16(1), 45-58.

Widyawati. (2015). Pelayanan, harga dan keputusan pembelian. 574-586. 